\title{
Could We Hack Women's Biological Clock? A Mitochondrial Hypothesis
}

\author{
Ana T Marcos and Jose M Navarro-Pando* \\ Department of Genetics, Instituto para el Estudio de la Biología de la Reproducción Humana INEBIR, Seville, Spain
}

Submission: December 04, 2017; Published: February 05, 2018

*Corresponding author: Jose M Navarro-Pando, INEBIR, Hospital Victoria Eugenia de la Cruz Roja, Avenida de la Cruz Roja 1,41009 Sevilla, Spain, Tel: +34954302683, Fax: +34955038621; Email: jose.navarro@inebir.com

\begin{abstract}
Our knowledge about aging infertility suggests that oocyte quality is the major contributing factor. Assisted reproductive technologies (ART) teach us two critical facts about this topic: the reduction of reproductive capacity observed in aged women is related with the oocyte's age, and how we can reverse the aging process getting high rates of live-birth pregnancies achieved by aged women with oocytes donated by younger women. The biologic reason why older women have a lower pregnancy rate is because aneuploid embryos are more frequently obtained from aged women. In this context, the quality of oocyte mitochondria is determinant in embryo quality, relating to euploid embryos, since mitotic non-disjunction occurs more frequently in advanced aged women [1].

Keywords: Oocytes age; Aneuploid embryos; Mitochondrial DNA; Mammalian embryos; Growth hormone; Mitochondria donation; Mitochondria transplant

Abbreviations: ART: Assisted Reproductive Technologies; mtDNA: mitochondrial DNA; FSH: Follicle-Stimulating Hormone; LH: Luteinizing
\end{abstract} Hormone; GH: Growth Hormone

\section{Mini Review}

\section{A mitochondrial hypothesis}

The oocyte is the largest cell in humans and it can contain 100.000 mitochondria. Each mitochondrion contains 1 to 15 mitochondrial DNA (mtDNA) molecules, then one single oocyte can contain between 50.000-1.500.000 copies of the mitochondrial genome [2]. mtDNA copy number per oocyte has been related with the probability of developing healthy oocytes $[3,4]$.

mtDNA is constantly replicating during oocyte maturation, but the number is stable after maturation (metaphase II oocytes). mtDNA level in human oocytes is inversely associated with maternal age and ovarian reserve clinical indicators [5]. Mountains of evidences show that older women's embryos have higher levels of mtDNA, which is correlated with implantation failure, and there is a threshold level of mtDNA above which implantation never occurred [6]. On the other hand, mtDNA level has found raised in aneuploid embryos compared to euploid embryos, independently of the maternal age [7]. That increased mtDNA has been correlated with elevated metabolism and reduced viability, consistent also with the "quiet embryo" hypothesis. This hypothesis proposes that the viability of early mammalian embryos is associated with a metabolism that is quiet rather than active [7-9]. The process of disjunction requires a significant amount of energy, provided by ATP from the mitochondria, and therefore, mitochondrial dysfunction is associated with oocyte aging and increased incidence of aneuploidy of maternal origin [10,11]. Duran et al. [5] have proposed that $\mathrm{mtDNA}$ quantification was more closely associated with Follicle-Stimulating Hormone (FSH) predicted reproductive age than with chronological age.

The mitochondria dysfunction is also associated with mtDNA mutations. The exposition of oocytes to harmful endogenous factors, as Reactive Oxygen Species and free radicals, while they are dormant, may cause mutations in the mtDNA. For example, a 4977-pb deletion was the most common deletion found in aged women, which represents the loss of several mitochondrial genes [7]. In the same way, a low expression of the PPARGC1A gene, involved in mitochondrial biogenesis and antioxidant activity, has been also described in women with diminished ovarian reserve [12].

\section{Strategies for improve ovarian quality}

Do we have a strategy to hack women's biological clock? One strategy is the addition of different supplements to culture media during ART with the idea of improving the embryo in vitro development, but that strategy is not universally accepted because some adverse negative effects were described [1315]. Silva et al. added antioxidants to culture media and the 


\section{Global Journal of Reproductive Medicine}

expression of oxidative stress genes was reduced, and more blastocysts were developed. Sato et al. added resveratrol to maturation medium and SIRT1 expression was observed, but no effect on mtDNA copy number in oocytes was detected.

Other approach is the administration of exogenous growth hormone $(\mathrm{GH})$ during standard ovarian stimulation regimens. An increase of mitochondrial function by GH has been observed in skeletal muscle cells, and also it was proposed that GH may acts increasing the FSH and luteinizing hormone (LH) receptors $[16,17]$. When GH was added before o during controlled ovarian stimulation, a higher embryo implantation and clinical pregnancy rates have been described, which is related with the capacity of GH to increases mitochondrial function, but it does not alter the yield of oocytes $[17,18]$.

Finally, the most exciting approaches is "mitochondria transplant" or "mitochondria donation", a set of in vitro techniques based on mitochondria replacement therapy by pronuclear transfer, spindle chromosome complex transfer, or polar body transfer [19-22]. All these methods exchange old mitochondria for younger ones from oocytes donors, increasing the developmental potential of the embryo and the pregnancy rates. This strategy has been used in some clinical human cases with promising but still controversial results.

\section{References}

1. Rabinowitz M, Ryan A, Gemelos G, Hill M, Baner J, et al. (2012) Origins and rates of aneuploidy in human blastomeres. Fertil Steril 97(2): 395401

2. Monnot S, Samuels DC, Hesters L, Frydman N, Gigarel N, et al. (2013) Mutation dependence of the mitochondrial DNA copy number in the first stages of human embryogenesis. Hum Mol Genet 22(9): 1867 1872.

3. May PP, Chretien MF, Malthiery Y, Reynier P (2007) Mitochondrial DNA in the oocyte and the developing embryo. Cur Top Dev Biol 77: 51-83.

4. Wai T, Ao A, Zhang X, Cyr D, Dufort D, et al. (2010) The role of mitochondrial DNA copy number in mammalian fertility. Biol Reprod 83(1): 52-62

5. Duran HE, Dimsek DF, Oehninger SC, Jones HW, Castora FJ (2011) The association of reproductive senescence with mitochondrial quantity, function, and DNA integrity in human oocytes at different stages of maduration. Fertil Steril 96(2): 384-388.

6. Diez JA, Rubio C, Marin C, Martinez S, Al-Asmar N, et al. (2015) Mitochondrial DNA content as a viability score in human euploid embryos: less is better. Fertil Steril 103(3): 534-541.

7. Fragouli E, Spath K, Alfarawatti S, Kaper F, Craig A, et al. (2015) Altered levels of mitochondrial DNA are associated with female age, aneuploidy, and provide an independent measure of embryonic implantation potential. PloS Genet 11(6): e1005241.

8. Baumann CG, Morris DG, Sreenan JM, Leese HJ (2007) The quiet embryo hypothesis: molecular characteristics favoring viability. Mol Reprod Dev 74(10): 1345-1353.

9. Tan Y, Yin X, Zhang S, Jiang H, Tan K, et al. (2014) Clinical outcome of preimplantation genetic diagnosis and screening using next generation sequencing. Gigascience 3(1): 30.

10. Bentov Y, Yavorska T, Esfandiari N, Jurisicova A, Casper RF (2011) The contribution of mitochondrial function to reproductive aging. J Assist Reprod Genet 28(9): 773-783.

11. Capalbo A, Bono s, Spizzichino L, Biricik A, Baldi M, et al. (2013) Sequential comprehensive chromosome analysis on polar bodies, blastomeres and trophoblast: insights into female meiotic errors and chromosomal segregation in the preimplantation window of embryo development. Hum Reprod 28(2): 509-518.

12. Boucret L, Chao BJM, Moriniere C, Desquiret V, Descamps P, et al. (2015) Relationship between diminished ovarian reserve and mitochondrial biogenesis in cumulus cells. Hum Reprod 30(7): 1653-1664.

13. Funakashi H, Day BN (1993) Effect of follicular fluid at fertilization in vitro on sperm penetration in pig oocytes. J Reprod Fertil 99(1): 97103.

14. Vatzias G, Hagen DR (1999) Effects of porcine follicular fluid and oviduct-conditioned media on maturation and fertilization of porcine oocytes in vitro. Biol Reprod 60(1): 42-48.

15. Mao J, Whitworth KM, Spate LD, Walters EM, Zhao J, et al. (2012) Regulation of oocyte mitochondrial DNA copy number by follicular fluid, EGF, and neuregulin 1 during in vitro maturation affects embryo development in pigs. Theriogenology 78(4): 887-897.

16. Short KR, Moller N, Bigelow ML, Coenen-Schimke J, Nair KS (2008) Enhancement of muscle mitochondrial function by growth hormone. J Clin Endocrinol Metab 93(2): 597-604.

17. Weall BM, Al-Samerria S, Conceicao J, Yovich JL, Almahbobi G (2015) A direct action for $\mathrm{GH}$ in improvement of oocyte quality in poorresponder patients. Reproduction 149(2): 147-154.

18. Yovich JL, Stanger JD (2010) Growth hormone supplementation improves implantation and pregnancy productivity rates for poorprognosis patients undertaking IVF. Reprod Biomed Online 21(1): 3749.

19. Craven L, Tuppen HA, Greggains GD, Harbottle SJ, Murphy JL, et al. (2010) Pronuclear transfer in human embryos to prevent transmission of mitochondrial DNA disease. Nature 465(7294): 82-85.

20. Zhang J, Liu H, Luo S, Lu Z, Chávez-Badiola A, et al. (2017) Live birth derived from oocyte spindle transfer to prevent mitochondrial disease. Reprod Biomed Online 34(4): 361-368.

21. Wang T, Sha H, Ji D, Zhang HL, Chen D, et al. (2014) Polar body genome transfer for preventing the transmission of inherited mitochondrial diseases. Cell 157(7): 1591-1604.

22. Sato D, Itami N, Tasaki H, Takeo S, Kuwayama T, et al. (2014) Relationship between mitochondrial DNA copy number and SIRT1 expression in porcine oocytes. PLoS One 9(4): e94488. 
(C) (i) This work is licensed under Creative

\section{Your next submission with Juniper Publishers will reach you the below assets}

- Quality Editorial service

- Swift Peer Review

- Reprints availability

- E-prints Service

- Manuscript Podcast for convenient understanding

- Global attainment for your research

- Manuscript accessibility in different formats ( Pdf, E-pub, Full Text, Audio)

- Unceasing customer service

Track the below URL for one-step submission https://juniperpublishers.com/online-submission.php 